\title{
PENGEMBANGAN MEDIA PEMBELAJARAN INTERAKTIF PADA MATA PELAJARAN MESIN KONVERSI ENERGI TEKNIK OTOMOTIF
}

\author{
Miptakul Arifin ${ }^{1}$, Abdul Hamid $K^{2}$, R. Mursid ${ }^{3}$ \\ ${ }^{1}$ SMK Negeri 2 Kisaran, Sumatera Utara \\ ${ }^{2,3}$ FT Universitas Negeri Medan, Sumatera Utara \\ miptakularifin@gmail.com
}

\begin{abstract}
Abstrak: Tujuan penelitian ini untuk: (1) menghasilkan media pembelajaran interaktif layak digunakan, mudah dipelajari siswa dan dipakai untuk pembelajaran individual, (2) untuk mengetahui keefektifan media pembelajaran interaktif pada mata pelajaran mesin konversi energi. Jenis penelitian pengembangan model Borg and Gall dan model desain pembelajaran Dick dan Carey. Model ini meliputi enam tahapan, yakni: studi literatur, perencanaan atau desain pengembangan, pengembangan produk, validasi ahli, uji coba, revisi, produk akhir. Hasil pengujian hipotesis membuktikan bahwa terdapat perbedaan yang signifikan antara hasil belajar siswa yang dibelajarkan dengan menggunakan media pembelajaran interaktif dengan hasil belajar siswa yang dibelajarkan dengan menggunakan media pembelajaran power point. Hal ini ditunjukkan dengan hasil pengolahan data diperoleh thitung $=3,328$ pada taraf signifikansi $\alpha=0.05$ dengan $d k 56$ diperoleh $t_{\text {tabel }}=1.67$, sehingga $t_{\text {hitung }}>t_{\text {tabel }}$, efektifitas penggunaan media pembelajaran interaktif $=80.46 \%$. Hasil belajar kelompok siswa yang dibelajarkan dengan menggunakan media pembelajaran interaktif sebesar 80,46\% lebih tinggi dari kelompok siswa yang dibelajarkan dengan menggunakan media pembelajaran power point sebesar $71.72 \%$. kelompok siswa yang dibelajarkan dengan menggunakan media pembelajaran power point sebesar $71.84 \%$.
\end{abstract}

Kata Kunci: media pembelajaran interaktif, mesin konversi energi, teknik otomotif

Abstract: The purpose of this study is to: (1) produce interactive learning media worthy of use, easy to learn for students and used for individual learning, (2) to determine the effectiveness of interactive learning media on energy conversion engine subjects. The type of research is the development of the Borg and Gall models and the learning design models of Dick and Carey. This model includes six stages, namely: literature study, planning or design development, product development, expert validation, trial, revision, final product. The results of hypothesis testing prove that there is a significant difference between the learning outcomes of students who are taught using interactive learning media and student learning outcomes learned by using power point learning media. This is indicated by the results of data processing obtained thitung $=3.328$ at the significance level $\alpha=0.05$ with dk 56 obtained t table $=1.67$, so that tcount $>t$ table, the effectiveness of using interactive learning media $=80.46 \%$. The group learning outcomes of students who were taught using interactive learning media amounted to $80.46 \%$ higher than the group of students who were taught using power point learning media at $71.72 \%$. the group of students studied using power point learning media at $71.84 \%$.

Keywords: interactive learning media, energy conversion machines, automotive techniques

\section{PENDAHULUAN}

SMK Negeri 2 Kisaran merupakan salah satu SMK Negeri yang ada di Kisaran yang memiliki beberapa program keahlian. Salah satu program keahlian tersebut adalah
Teknik Otomotif. Pembelajaran di sekolah menengah kejuruan untuk program keahlian Teknik Otomotif memerlukan pengetahuan teoretis yang cukup, disertai dengan pengetahuan praktis yang mudah dipahami. 
Menguasai konsep dasar mesin konversi energi adalah salah satu mata pelajaran yang diberikan pada program keahlian Teknik Otomotif. Mata pelajaran mesin konversi energi merupakan mata pelajaran yang sangat penting untuk memahami dasar-dasar teknik otomotif seperti motor bakar, motor listrik, generator listrik, pompa fluida, kompressor dan refrigrasi.

Berdasarkan survei yang dilakukan penulis di SMK Negeri 2 Kisaran, dengan mendengar pendapat guru mata pelajaran produktif Bapak Sarjono, S.Pd, hasil belajar siswa kelas X Program Keahlian Teknik Otomotif untuk mata pelajaran mesin konversi energi masih berjalan secara konvensional yaitu didominasi melalui kegiatan ceramah dalam pembelajaran dan berpusat pada guru. Hal ini didukung pengamatan peneliti terhadap kegiatan pembelajaran mesin konversi energi yang dilakukan di SMK Negeri 2 Kisaran ditemukan bahwa kecenderungan guru mengajarkan mata pelajaran mesin konversi energi dalam memberikan pemahaman terhadap konsep, selalu dilakukan melalui satu teknik penyampaian saja, sehingga siswa kurang bergairah dan tidak begitu antusias ketika pelajaran berlangsung.

Berdasarkan hasil wawancara kepada beberapa siswa, bahwa para siswa menganggap pelajaran mesin konversi energi termasuk mata pelajaran yang sulit, tidak menarik dan membosankan dikarenakan kurangnya media yang mendukung pembelajaran mesin konversi energi untuk membantu pemahaman siswa. Siswa menganggap pelajaran mesin konversi energi tidak perlu disampaikan secara teori tetapi dilaksanakan dengan praktikum tanpa memahami konsep dasar dari pelajaran mesin konversi energi. Oleh karena itu, diperlukan suatu upaya yang tepat untuk mengatasi masalah-masalah pada pembelajaran mata pelajaran produktif khususnya mesin konversi energi. Salah satu upaya yang dapat dilakukan untuk meningkatkan hasil belajar siswa adalah meningkatkan kualitas pembelajaran dengan menggunakan media pembelajaran interaktif.

Masalah hasil belajar siswa tidak terlepas dari masalah pembelajaran. Hal ini karena pembelajaran memiliki peranan yang sangat penting pada hasil belajar. Peningkatan hasil belajar menunujukkan pada upaya peningkatan kualitas proses dan hasil pembelajaran. Berdasarkan audensi peneliti ke Dinas Pendidikan Kabupaten Asahan melalui sekretaris dinas pendidikan bapak Drs. H. Darmawan, M.Pd dan kepala bidang pendidikan menengah bapak bapak Herlis, S.Pd salah satu usaha dalam peningkatan hasil belajar yang sesuai dengan perkembangan ilmu pengetahuan dan teknologi (IPTEK) serta era globalisasi adalah adanya pengguanaan media pembelajaran interaktif berbasis pada kemajuan teknologi informasi dan komunikasi (TIK). Untuk itu setiap guru dituntut agar tetap meningkatkan kualitas dalam merancang media pembelajaran yang digunakan dalam menyampaikan materi pelajaran sehingga hasil belajar dapat optimal.

Kehadiran media pembelajaran interaktif dalam proses belajar mengajar dengan pengembangan Borg \& Gall dan dipadukan dengan pengembangan instruksional Dick \& Carey telah membuat suasana yang berbeda dalam kelas, karena materi yang dulunya diajarkan dengan ceramah dan hanya monoton dapat divariasi dengan menampilkan tayangan berupa integrasi teks, suara, gambar bergerak dan video.

Media sebagai alat bantu dalam pembelajaran membantu siswa mencerna dan atau memahami substansi materi pelajaran yang sukar terutama yang rumit dan kompleks, Menurut Hamalik (1994:6) menyatakan bahwa guru dituntut agar mampu memahami, menggunakan alat-alat yang tersedia dalam upaya mencapai tujuan tujuan pembelajaran yang diharapkan. Dari pernyataan tersebut, tersirat bahwa pengajar harus memiliki pengetahuan dan pemahaman yang cukup mengenai media pembelajaran. Apalagi pada masa sekarang ini, teknologi informasi sudah mengalami kemajuan pesat, suka tidak suka para pengajar sudah seharusnya lebih membuka diri menguasai teknologi informasi guna mendukung terciptanya proses belajar yang menarik, efesien, dan terciptanya tujuan pembelajaran. Hadirnya multimedia interaktif disambut baik dalam dunia pendidikan, karena pembelajaran menjadi lebih menarik dan interaktif, lebih hemat waktu, tidak terikat pada ruangan kelas sehingga sikap siswa terhadap belajar dapat ditingkatkan, serta Peraturan Menteri Pendidikan Nasional (Permendiknas) Nomor 41 tahun 2007 menuntut guru untuk merencanakan dan mengembangkan materi pembelajaran. Saat ini animasi sudah mampu diintegrasikan dengan program komputer dan 
mulai diterapkan dalam media pendidikan, dinamakan media pembelajaran interaktif.

Pembelajaran mesin konversi energi menekankan antara lain pada pemberian pengalaman secara langsung melalui berbagai aktivitas. Identifikasi yang merupakan salah satu aktivitas pada pembelajaran mesin konversi energi, merupakan kegiatan yang memerlukan ketelitian siswa antara lain melalui pengamatan. Pembelajaran mesin konversi energi menuntut siswa untuk menguasai kemahiran berfikir kreatif, kemampuan daya visualisasi yang tinggi dan kemahiran dalam menggambarkan objek keseluruhan, siswa juga dituntut untuk menjelaskan pelajaran mesin konversi energi secara visual konsep, prinsip dan langkah kerja dalam setiap objek mesin konversi energi. Langkah ini merupakan salah satu upaya mengatasi tantangan tersebut dan turut membantu dalam mempercepat dan meningkatkan kualitas pembelajaran terutama di bidang teknik otomotif.

Perkembangan ilmu pengetahuan dan teknologi yang terjadi saat ini semakin mendorong upaya-upaya pembaharuan dalam pemanfaatan hasil-hasil teknologi dalam proses belajar. Penggunaan dan pengembangan media pembelajaran merupakan salah satu strategi yang dapat dilakukan oleh guru agar peran serta dan partisipasi siswa dalam proses belajar mengajar dapat ditingkatkan. Berdasarkan hasil studi pendahuluan dengan menganalisis kebutuhan guru dan siswa yang diperoleh penulis di SMK Negeri 2 Kisaran bahwa 87,5\% guru dan $100 \%$ siswa membutuhkan media pembelajaran interaktif dalam proses pembelajaran.

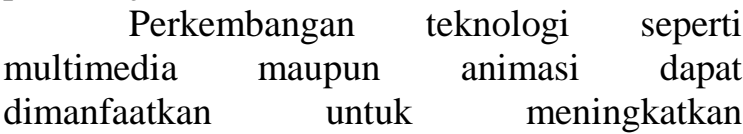

keterampilan proses siswa yang secara tidak langsung juga meningkatkan kulitas pendidikan, apalagi jika media yang digunakan sesuai dengan kebutuhan dan perkembangan zaman. Hal ini menuntut seorang guru untuk mampu mengembangkan media yang menarik dan melibatkan lingkungan sekitar sehingga dapat membantu siswa dalam memahami dan memaknai pelajaran mesin konversi energi dalam kehidupannya. Konsep motor bakar merupakan salah satu kompetensi dasar yang ada pada mata pelajaran mesin konversi energi yang sering dijumpai di lingkungan sekitar. Motor bakar merupakan mesin yang mengubah tenaga panas menjadi tenaga mekanik. Meskipun jenis motor bakar cukup beragam, namun tidak banyak pengetahuan tentang motor bakar yang disampaikan untuk dipelajari atau menjadi bahan kajian bagi siswa. Oleh sebab itu, berkaitan dengan optimalisasi pemanfaatan media pembelajaran interaktif dan upaya mentransformasikan hasil pembelajaran motor bakar, tampaknya perlu dilakukan pengembangan media pembelajaran interaktif pada mata pelajaran mesin konversi energi pada siswa kelas X Teknik Otomotif SMK Negeri 2 Kisaran sebagai sumber belajar siswa.

\section{Hakikat Belajar dan Hasil Belajar Mesin Konversi Energi}

Belajar merupakan aktivitas paling utama dalam keseluruhan proses pendidikan. Keberhasilan pencapaian tujuan pendidikan tergantung pada bagaimana proses belajar dapat berlangsung secara efektif. Badar (2014:18) menyebutkan bahwa belajar merupakan perubahan yang meliputi perubahan pengetahuan, pemahaman, keterampilan dan kebiasaan yang baru yang diperoleh individu. Belajar menurut Hill (dalam Mursid,2013:61) adalah terjadi ketika pengalaman menyebabkan perubahan yang relative permanen dalam pengetahuan individu atau perilaku. Perubahan ini mungkin disengaja atau tidak disengaja, untuk lebih baik atau buruk, benar atau salah, dan sadar atau unconscious. Belajar menurut Sanjaya (2006:112) adalah proses mental yang terjadi dalam diri seseorang, sehingga menyebabkan munculnya perubahan perilaku. Slameto (2003:2) menyebutkan bahwa belajar adalah suatu proses usaha yang dilakukan seseorang untuk memperoleh suatu perubahan tingkah laku yang baru secara keseluruhan, sebagai hasil pengalamannya sendiri dalam interaksi dengan lingkungannya.

Belajar menurut Gagne dikutip oleh (Slameto 2008:11) merupakan suatu proses usaha sadar yang dilakukan oleh individu untuk suatu perubahan dari tidak tahu menjadi tahu, dari tidak memiliki sikap menjadi bersikap benar, dari tidak terampil menjadi terampil melakukan sesuatu. Salah satu defenisi belajar yang cukup sederhana namun mudah diingat adalah yang dikemukakan oleh Gagne (dalam Afrizar,2014:15) "Learning is relatively permanent change in behavior that result from past experience or purposeful instruction". Belajar adalah suatu perubahan perilaku yang 
relative menetap yang dihasilkan dari pengalaman masa lalu ataupun dari pembelajaran yang bertujuan atau direncanakan.

Menurut Gagne dan Briggs (1979:52), "prestasi belajar dapat dikelompokkan ke dalam 5 (lima) kategori yaitu : (1) keterampilan intelektual, (2) informasi verbal, (3) strategi kognitif, (4) keterampilan motorik, dan (5) sikap. Pendapat ini diartikan : Pertama, keterampilan intelektual (intellectual skills). Belajar keterampilan intelektual berarti belajar bagaimana melakukan sesuatu secara intelektual. Ada enam jenis keterampilan intelektual, : (1) diskriminasi-diskriminasi, yaitu kemampuan membuat respons yang berbeda terhadap stimulus yang berbeda pula; (2) konsep-konsep konkret, yaitu kemampuan mengidentifikasi ciri-ciri atau atribut-atribut suatu objek; (3) konsep-konsep terdefinisi, yaitu kemampuan memberikan makna terhadap sekelompok objek-objek, kejadian-kejadian, atau hubungan-hubungan; (4) aturan-aturan, yaitu kemampuan merespons hubunganhubungan antara objek-objek dan kejadiankejadian; (5) aturan tingkat tinggi, yaitu kemampuan merespons hubungan-hubungan antara objek-objek dan kejadian-kejadian secara lebih kompleks; (6) memecahkan masalah, yaitu kemampuan memecahkan masalah yang biasanya melibatkan aturan-aturan tingkat tinggi. Kedua, strategi-strategi kognitif (cognitive strategies). Strategi-strategi ini merupakan kemampuan yang mengarahkan prilaku belajar, mengingat, dan berpikir seseorang. Ada lima jenis strategi-strategi kognitif : (1) strategi-strategi menghafal, yaitu strategi belajar yang dilakukan dengan cara menghafal ide-ide dari sebuah teks; (2) strategistrategi elaborasi, yaitu strategi belajar dengan cara mengaitkan materi yang dipelajari dengan materi lain yang relevan; (3) strategi-strategi pengaturan, yaitu strategi belajar yang dilakukan dengan cara mengelompokkan konsep-konsep agar menjadi kategori-kategori yang bermakna; (4) strategi-strategi pemantauan pemahaman, yaitu strategis belajar yang dilakukan dengan cara memantau prosesproses belajar yang sedang dilakukan; (5) strategi-strategi afektif, yaitu strategi belajar yang dilakukan dengan cara memusatkan dan mempertahankan perhatian. Ketiga, informasi verbal (verbal information). Belajar informasi verbal adalah belajar untuk mengetahui apa yang dipelajari baik yang berbentuk nama-nama objek, fakta-fakta, maupun pengetahuan yang telah disusun dengan baik. Keempat, keterampilan motor (motor skills). Kemahiran ini merupakan kemampuan siswa untuk melakukan sesuatu dengan menggunakan mekanisme otot yang dimiliki. Kelima, sikap (attitudes). Sikap merupakan kemampuan mereaksi secara positif atau negatif terhadap orang, sesuatu, dan situasi.

Menurut Mursid (2013:74) mengatakan bahwa hasil belajar adalah kemampuan siswa dalam menyerap materi pelajaran juga dalam melakukan kegiatan praktek sesuai dengan proses pembelajaran. hasil belajar yang esensial adalah penguasaan aspek kompetensi siswa meliputi kognitif, afektif, dan psikomotorik.Hasil belajar adalah dari suatu interaksi tindakan belajar dan mengajar. Guru memberikan bahan pelajaran dan mengakhirinya dengan pemberian evaluasi. Dimyati dan Mujiono dikutip oleh Dewi (2011:12) mengatakan bahwa dampak pengajaran adalah hasil yang dapat diukur atau kemampuan seperti yang tertuang dalam angka raport, angka ijazah atau kemampuan meloncat dibidang lain yang merupakan suatu transfer dalam belajar.

Hasil Belajar didefinisikan oleh Romiszowski (1981:63) sebagai output (keluaran) dari suatu pemrosesan input (masukan). Input dapat berupa informasi sedangkan output berupa performance (kinerja). Kinerja memberi petunjuk bahwa proses belajar telah terjadi. Romozowski membagi hasil belajar ke dalam dua kategori yaitu pengetahuan dan keterampilan. Pengetahuan dikelompokan pada empat kategori yaitu : (1) fakta, merupakan pengetahuan tentang objek nyata, hubungan dari keyataan, dan informasi verbal dari suatu objek, peristiwa atau manusia; (2) konsep, merupakan pengetahuan tentang seperangkat objek konkrit atau defenisi; (3) prinsip, merupakan pernyataan yang mengenai hubungan dari dua konsep atau lebih; (4) prosedur, merupakan pengetahuan tentang tindakan demi tindakan yang bersifat linier dalam mencapai suatu tujuan.

Reigeluth (1983) berpendapat bahwa hasil pembelajaran harus memiliki efektivitas, efisiensi, dan daya tarik. Efektivitas diukur dari tingkat pencapaian hasil belajar yang diperoleh oleh peserta didik, baik secara kualitas maupun secara kuantitas. Secara kualitas hasil belajar 
menunjukan kebermaknaan isi bahan yang dipelajari dalam kehidupan sehari-hari. Sedangkan kuantitas menunjukan jumlah variasi hasil belajar yang dapat dicapai oleh peserta didik. Efisiensi diukur berdasarkan waktu yang dibutuhkan peserta didik untuk belajar, dalam arti semakin sedikit waktu yang dibutuhkan peserta didik untuk memahami isi materi pelajaran, maka semakin efisien hasil belajar yang diperoleh. Sedangkan daya tarik diukur dari ada tidaknya kecenderungan peserta didik termotivasi untuk belajar labih lanjut dalam arti mengembangkan wawasan berdasarkan hasil belajar yang telah diperoleh.

\section{Hakikat Media Pembelajaran Interaktif}

Secara umum media merupakan kata jamak dari "medium", yang berarti perantara atau pengantar. Istilah media digunakan untuk bidang pengajaran atau pendidikan sehingga istilahnya menjadi media pendidikan atau media pembelajaran (Sanjaya, 2010:163). Dalam bahasa Arab media adalah perantara atau pengantar pesan dari pengirim pesan (Arsyad, 2002:3). Tetapi secara lebih khusus, pengertian media dalam proses pembelajaran diartikan sebagai alat-alat grafis, fotografis, atau elektronik untuk menangkap, memproses, dan menyusun kembali informasi visual atau verbal. Media juga dapat diartikan sebagai segala sesuatu yang dapat dipergunakan untuk menyalurkan pesan, merangsang pikiran, perasaan, perhatian, dan kemauan siswa, sehingga dapat terdorong terlibat dalam proses pembelajaran.

Menurut Sabri (2007:108) menyatakan bahwa media pembelajaran merupakan alat yang digunakan sebagai perantara untuk menyampaikan pesan dan dapat merangsang pikiran, perasaan dan kemajuan audiend (peserta didik) sehingga dapat mendorong terjadinya proses belajar mengajar. Miarso (dalam Munadi, 2008:4) berpendapat bahwa media yang dirancang dengan baik dalam batas tertentu dapat merangsang timbulnya semacam dialog internal dalam diri peserta didik yang belajar. Dengan perkataan lain terjadi komunikasi antara peserta didik dengan media atau secara tidak langsung antara peserta didik dengan sumber pesan atau pendidik. Media berhasil membawakan pesan belajar bila kemudian terjadi perubahan kualitas dalam diri peserta didik. Kehadiran media akan membuat pendidik dapat meningkatkan minat peserta didik dalam proses belajar mengajar dan peserta didik dapat lebih cepat memahami dan mengerti terhadap materi yang disampaikan pendidik.

Dzamarah (2006:121) mengemukakan bahwa media pembelajaran adalah segala sesuatu yang dapat dipergunakan untuk menyalurkan pesan dari pengirim ke penerima sehingga dapat merangsang pikiran, perasaan, perhatian, dan minat siswa sedemikian rupa sehingga terjadi proses belajar. Media pembelajaran dalam arti yang luas adalah bahwa media tidak hanya meliputi media komunikasi elektronik yang kompleks, tetapi juga mencakup alat-alat sederhana, seperti, slide, fotografi, diagram, dan bagan buatan guru, objek-objek nyata serta kunjungan ke luar sekolah Hamalik (2005:202). Gerlach dan Ely (Sanjaya 2010:163) mengatakan bahwa media pendidikan apabila dipahami secara garis besar adalah manusia, materi, atau kejadian yang membangun kondisi yang mebuat siswa mampu memperoleh pengetahuan, ketrampilan atau sikap. Guru, buku, teks dan lingkungan sekolah merupakan media.

$$
\text { Menurut Binanto }
$$

Macromedia flash 8 ialah sebuah software yang memiliki banyak fungsi. Selain digunakan untuk membuat animasi kartun program atau software ini juga dapat digunakan untuk membuat animasi pada Web, CD tutorial, presentasi produk, aplikasi interaktif, game edukasi sederhana, presentasi untuk tugas kuliah dll. Dalam proses pembelajaran Macromedia Flash digunakan sebagai media dalam bentuk presentasi multimedia yang interaktif.

Powerpoint adalah perangkat lunak presentasi yang dirancang untuk memungkinkan anda dalam membuat persuasif, presentasi profesional. Dengan menempatkan konten-termasuk teks, grafis, animasi, grafik, foto, dan banyak lagi-pada slide, Powerpoint memungkinkan anda untuk membuat sebuah alat bantu visual untuk semua jenis presentasi publik. Anda mungkin memilih untuk menggunakan Power Point jika Anda perlu untuk membuat tangan keluar, slide show, presentasi, sertifikat atau lebih. (http://guides.library.msstate.edu, 2012). Berdasarkan beberapa teori-teori tersebut diatas maka dapat dikatakan bahwa, Media Powerpoint adalah salah satu alat atau saluran yang bermanfaat untuk mempermudah dalam menyampaikan dan memperoleh berbagai 
informasi terutama didalam kegiatan atau proses pembelajaran.

Menurut Seels dan Glasgow dalam Arsyad (2006:36) mengemukakan bahwa media interaktif merupakan sistem media penyampaian yang menyajikan materi video rekaman dengan pengendalian komputer kepada penonton (siswa) yang tidak hanya mendengar dan melihat video dan suara, tetapi juga memberikan respon yang aktif dan respon itu yang menentukan kecepatan dan sekuensi penyajian. Media interaktif memiliki unsur audio-visual (termasuk animasi) dan disebut interaktif karena media ini dirancang dengan melibatkan respon pemakai secara aktif. Selain itu menurut Kamus Besar Bahasa Indonesia (KBBI) media interaktif adalah alat perantara atau penghubung berkaitan dengan komputer yang bersifat saling melakukan aksi antarhubungan dan saling aktif .

Dalam pengembangan media pembelajaran interaktif pada mata pelajaran Geografi digunakan model pengembangan produk Borg dan Gall (2005), dan untuk mengembangkan recana pembelajarannya dipadukan dengan model pengembangan pembelajaran model Dick \& Carey (2005).

Sukmadinata (2010:13) menjelaskan

"Jika kesepuluh langkah penelitian dan pengembangan diikuti dengan benar, maka akan dapat menghasilkan suatu produk pendidikan yang dapat dipertanggungjawabkan”. Langkahlangkah tersebut bukanlah hal baku yang harus diikuti, langkah yang diambil bisa disesuaikan dengan kebutuhan peneliti. Untuk menghasilkan produk media pembelajaran interaktif diperlukan perencanaan, perancangan pembelajaran yang baik.

Rumusan masalah penelitian adalah: (1) Apakah media pembelajaran interaktif dengan menggunakan Macromedia Flash Profesional 8.0 pada mata pelajaran mesin konversi energi layak digunakan?; (2) Apakah media pembelajaran interaktif Macromedia Flash Profesional 8.0 yang dikembangkan pada mata pelajaran mesin konversi energi efektif dibandingkan dengan media power point pada siswa?

\section{METODE}

Penelitian ini dilakukan di SMK Negeri 2 Kisaran yang terletak di Jalan Sei Renggas Nomor 1 Kisaran pada siswa kelas X Program Keahlian Teknik Otomotif semester genap.
Model pengembangan yang digunakan dalam pengembangan media pembelajaran ini adalah model pengembangan Borg and Gall (1983) yang dipadu dengan model pengembangan pembelajaran model Dick dan Carey (2005). Adapun langkah-langkah dari tahapan pengembangannya adalah sebagai berikut :

1. Melakukan penelitian pendahuluan, yang meliputi:

a. Identifikasi kebutuhan pembelajaran dan menentukan standar kompetensi mata pelajaran.

b. Melakukan analisis pembelajaran.

c. Mengidentifikasi karakteritik dan perilaku awal peserta didik.

d. Menulis kompetensi dasar dan indikatornya.

e. Menulis tes acuan patokan.

f. Menyusun strategi pembelajaran yang terdiri dari, (1). Penjelasan tentang tujuan instruksional, 2). Penjelasan relevansi isi pelajaran baru, (3). Penjelasan Penjelasan tentang materi pelajaran atau konsep, prinsip, dan prosedur yang akan dipelajari peserta didik, (4). Tes formatif dan umpan balik, (5). Tindak lanjut.

g. Mengembangkan bahan pembelajaran.

2. Pembuatan desain software, yang meliputi:
a. Pembuatan naskah
b. Pembuatan storyboard
c. Pembuatan Flowchart View

3. Pengumpulan bahan, yang meliputi:

a. Pembuatan dan pengumpulan gambar (image) dan animasi.

b. Perekaman dan pengumpulan audio

4. Mengembangkan dan membuat media pembelajaran interaktif

5. Review dan uji coba produk.

6. Uji keefektifan produk

\section{Tahap Uji Coba Produk}

Desain uji coba tahap-tahapnya adalah sebagai berikut:

a. Validasi ahli materi otomotif

b. Validasi ahli perangkat lunak

c. Validasi ahli desain instruksional

d. Analisis konseptual

e. Revisi pengembangan (tahap I), berdasarkan penilaian yang berupa masukan, kritik atau saran dari 2 ahli materi, 2 ahli perangkat lunak dan 2 ahli desain instruksional untuk dilakukan perbaikan.

f. Uji coba satu-satu/perorangan 
g. Analisis konseptual

h. Revisi pengembangan (tahap II), berdasarkan penilaian yang berupa masukan, kritik atau saran dari 3 siswa program keahlian teknik otomotif kelas X SMK Negeri 2 Kisaran yang memiliki prestasi tinggi, sedang dan rendah.

i. Uji coba kelompok kecil. Penilaian terhadap program ini berdasarkan angket yang telah diisi oleh 9 siswa program keahlian teknik otomotif kelas X SMK Negeri 2 Kisaran.

j. Analisis konseptual dan produk

k. Revisi produk (tahap III)

1. Uji coba lapangan terhadap 29 siswa program keahlian teknik otomotif kelas X SMK Negeri 2 Kisaran

m. Penilaian mengenai daya tarik dan kelayakan produk

n. Analisis empirik (tahap IV)

o. Revisi kecil

p. Uji efektifitas produk

Produk pengembangan media pembelajaran interaktif memerlukan balikanbalikan dalam rangka evaluasi formatif. Balikan-balikan tersebut diperoleh dari para subjek yang terdiri dari 2 orang ahli desain pembelajaran, 2 orang ahli materi, 2 orang ahli perangkat lunak, dan pemakai produk yaitu peserta didik SMK Negeri 2 Kisaran yang teridiri dari 3 orang siswa kelas $\mathrm{X}$ program keahlian teknik otomotif untuk uji coba satusatu, 9 orang siswa kelas $\mathrm{X}$ program keahlian teknik otomotif untuk uji coba kelompok kecil dan 29 siswa kelas X program keahlian teknik otomotif untuk uji coba lapangan.

Analisis data dalam penelitian ini menggunakan analisis deskriptif kuantitatif. Semua data yang terkumpul dianalisis dengan teknik statistik deskriptif yang secara kuantitatif dipisahkan menurut kategori untuk mempertajam penilaian dalam menarik kesimpulan. Data kualitatif yang berupa pernyataan sangat kurang Layak, kurang Layak, sedang, Layak dan Sangat Layak diubah menjadi data kuantitatif dengan skala nilai 1 sampai 5. Hasilnya dirata-rata dan digunakan untuk menilai kualitas software pembelajaran. Kriteria software akan dikonversikan menjadi nilai dengan skala lima menggunakan Skala Likert yang dianalisis secara deskriptif persentase dengan rumus sebagai berikut (Sugiyono,2011:318):

$$
X=\frac{\text { Jumlah } \text { skor diperoleh }}{\text { Jumlah skor ideal seluruh item }} \times 100 \%
$$

Tabel 1. Kriteria Jawaban Item Instrumen Validasi Dengan Jenis Skala Likert Beserta Skornya

\begin{tabular}{clc}
\hline Nilai & \multicolumn{1}{c}{ Kriteria } & Persentase \\
\hline A & Sangat Layak & $80 \% \leq X \leq 100 \%$ \\
B & Layak & $60 \% \leq X \leq 100 \%$ \\
C & Sedang & $40 \% \leq X \leq 60 \%$ \\
D & Kurang Layak & $20 \% \leq X \leq 40 \%$ \\
E & Sangat Kurang & $0 \% \leq X \leq 20 \%$ \\
\hline
\end{tabular}

\section{Metode Penelitian Tahap II}

Penelitian ini di laksanakan di SMK Negeri 2 Kisaran yang terlelangkah di Jalan Sei Renggas Nomor 1 Kisaran pada siswa Program keahlian teknik otomotif kelas $\mathrm{X}$ semester genap Tahun Pelajaran 2015-2016. Pelaksanaannya pada bulan Januari 2016. Perlakuan (eksperimen) dilaksanakan selama 2 kali pertemuan dengan alokasi waktu 2 x 45 menit tiap pertemuan. Proses pembelajaran dilaksanakan di kelas.

Populasi dalam penelitian ini adalah seluruh siswa kelas X SMK Negeri 2 Kisaran Tahun Pelajaran 2015-2016 yang berjumlah 2 kelas (58 siswa). Dari seluruh populasi ditentukan sampel sebanyak 2 kelas yaitu $\mathrm{X}$ TO-1 sebagai kelas kontrol dengan jumlah peserta didik sebanyak 29 orang dan kelas $X$ TO-2 sebagai kelas perlakuan dengan jumlah peserta didik sebanyak 29 orang.

Penelitian ini melibatkan dua kelas, yaitu kelas eksperimen dan kelas kontrol dimana keduan kelas ini diberi tes sebanyak sekali yakni tes yang diberikan sesudah perlakuan disebut post-test only.

AdapunLangkah-langkah yang akan ditempuh dalam melaksanakan penelitian ini adalah :

\section{Tahap awal}

a. Memberi informasi kepada pihak SMK Negeri 2 Kisaran, perihal kegiatan penelitian ini.

b. Membuat jadwal penelitian.

c. Menyusun rencana pembelajaran

d. Perlakuan

e. Post test

Penelitian ini dilaksanakan pada semester genap Tahun Pelajaran 2015-2016 dengan sampel yang terdiri dari dua kelas berjumlah 58 orang peserta didik dengan kelas 
X TO-1 sebagai kelas kontrol yang diajar dengan pembelajaran menggunakan media power point sebagaimana yang berlangsung selama ini dan kelas X TO-2 sebagai kelas eksperimen/perlakuan yang mengunakan media pembelajaran interaktif. Untuk mendapatkan hasil akhir diberikan tes pada kedua kelas dengan instrumen yang sama yaitu tes obyektif. Instrumen yang digunakan yaitu tes hasil belajar yang berbentuk pilihan bergandayang berjumlah 15 soal yang masingmasing terdiri dari 5 opsi yaitu a, b, c, d, dan e . Teknik pemberian skor untuk soal objektif ini berdasarkan jawaban benar, artinya bagi siswa yang menjawab benar pada setiap butir soal akan diberikan skor 1 (satu) dan bagi siswa yang menjawab salah akan diberikan skor nol (nol). Sehingga skor minimal adalah 0 .

Namun sebelum instrumen penelitian digunakan untuk menguji efektifitas penggunaan media pembelajaran interaktif, maka instrumen penelitian tersebut harus diujicobakan terlebih dahulu dan diikuti dengan analisis butir soal agar instrumen penelitian dapat dikalangkahan Layak, valid dan reliabel. Untuk uji coba dilakukan pada responden diluar dari sampel. Cara yang ditempuh adalah memberikan tes kepada siswa yang terpilih sebagai responden uji coba. Untuk hasil belajar mesin konversi energi dilakukan pada siswa kelas X program keahlian teknik otomotif SMK Negeri 2 Kisaran yang berjumlah 58 orang.

Analisis data pada penelitian ini menggunakan teknik analisis kuantitatif. Sebelum dilakukan uji hipotesis, terlebih dahulu dilakukan uji persyaratan yaitu uji normalitas dan uji homogenitas. Uji normalitas dilakukan untuk mengetahui apakah skor variable yang diteliti berasal dari populasi yang berdistribusi normal. Untuk mengetahui hal ini dilakukan dengan menggunakan uji Chi Kuadrat sebagai berikut (Sugiyono, 2011:318):

$$
x^{2}=\sum \frac{(f o-f h)^{2}}{f h}
$$

Keterangan:

$$
\begin{aligned}
\chi^{2} & =\text { Chi-kuadrat yang dihitung } \\
\text { fo } & =\text { frekuensi observasi } \\
\text { fh } & =\text { frekuensi harapan }
\end{aligned}
$$

Gejala yang diamati berdistribusi normal jika $\chi^{2}$ hitung $<\chi^{2}$ tabel pada signifikasi 0,05 .
Untuk menguji homogenitas data, digunakan uji kesamaan dua varians. Dalam hal ini pengujian kesamaan varians kedua populasi pada data hasil belajar adalah sebagai berikut:

Ho $; a_{1}^{2}=a_{2}{ }^{2}$ dan $\mathrm{Ha}: a_{1}{ }^{2} \quad a_{2}{ }^{2}$

Dilakukan uji dua pihak dengan taraf signifikansi 0,05 , hipotesis diatas diuji dengan statistika:

$$
F=\frac{\text { Variansterbesar }}{\text { Variansterkecil }}
$$

Kriteris pengujian hipotesis:

Ho diterima jika $F \quad F(V 1, V 2)$ dan Ho ditolak jika $\mathrm{F} \quad \mathrm{F}(\mathrm{V} 1, \mathrm{~V} 2)$

Untuk melihat apakah ada perbedaan yang signifikan antara hasil belajar dengan penggunaan media pembelajaran interaktif dan buku teks maka dilakukan uji hipotesis dengan uji t, sebagai berikut:

$$
\begin{aligned}
& t_{\text {hitung }}=\frac{\overline{x 1}-\overline{x 2}}{S D \sqrt{\frac{1}{n_{1}}+\frac{1}{n 2}}} \\
& \text { dengan } S D=\sqrt{\frac{\left(n_{1}-1\right) s_{1}^{2}+\left(n_{2}-1\right) s_{2}^{2}}{n_{1}+n_{2}-2}}
\end{aligned}
$$

dengan $d b=n_{1}+n_{2}-2$ kriteria korelasi yang diperoleh dikalangkahan signifikan ( hipotesis diterima) jika harga $\mathrm{t}$ hitung $>\mathrm{t}$ tabel untuk taraf signifikasi 0,05 .

Keterangan:

Untuk melihat keefektifan media pembelajaran interaktif yang dieksperimenkan digunakan rumus perhitungan efektifitas berikut (Sugiyono, 2011:318):

$$
X=\frac{\text { Jumlah skor yang diperoleh }}{\text { Jumlah skor ideal seluruh item }} \times 100 \%
$$

\section{HASIL PENELITIAN}

Uji coba lapangan juga dilakukan di SMK Negeri 2 Kisaran . Uji coba lapangan Program studi keahlian teknik otomotif yang teridiri dari 58 siswa dari dua kelas yaknik kelas TO-I sebanyak 29 siswa dan kelas TO-II sebanyak 29 siswa. Uji coba lapangan menghasilkan data-data yang nantinya akan mengukur kelayakan dari produk yang dikembangkan, serta untuk mengetahui bagaimana manfaat produk tersebut bagi pemakainya. 
Tabel 1. Skor Penilaian Media Pembelajaran Interaktif Mesin konversi energi Uji Coba Lapangan Pada Aspek Kualitas Materi Pembelajaran

\begin{tabular}{|c|c|c|c|c|c|c|c|c|}
\hline \multirow{2}{*}{ No } & \multirow{2}{*}{ Indikator Penilaian } & \multicolumn{5}{|c|}{ Skor } & \multirow{2}{*}{ Rata-rata } & \multirow{2}{*}{ Kriteria } \\
\hline & & 1 & 2 & 3 & 4 & 5 & & \\
\hline 1 & Kesesuaian materi & & & & 6 & 52 & $97,93 \%$ & Sangat Layak \\
\hline 2 & Kejelasan petunjuk belajar & & & & 3 & 55 & $98,97 \%$ & Sangat Layak \\
\hline 3 & $\begin{array}{l}\text { Kemudahan memahami } \\
\text { kalimat pada teks }\end{array}$ & & & & 13 & 45 & $95,52 \%$ & Sangat Layak \\
\hline 4 & $\begin{array}{l}\text { Kemudahan memahami } \\
\text { pembelajaran }\end{array}$ & & & & 10 & 48 & $96,55 \%$ & Sangat Layak \\
\hline 5 & Ketepatan urutan penyajian & & & & 5 & 53 & $98,28 \%$ & Sangat Layak \\
\hline 6 & Kecukupan latihan & & & & 13 & 45 & $95,52 \%$ & Sangat Layak \\
\hline 7 & Kejelasan umpan balik & & & & & 58 & $100,00 \%$ & Sangat Layak \\
\hline 8 & $\begin{array}{l}\text { Bantuan belajar dengan } \\
\text { program }\end{array}$ & & & & & 58 & $100,00 \%$ & Sangat Layak \\
\hline \multicolumn{3}{|c|}{ Rata-rata } & & & & & $97,84 \%$ & Sangat Layak \\
\hline
\end{tabular}

Tabel 2. Skor Penilaian Media Pembelajaran Interaktif Berbasis Komputer Pada Mata Pelajaran Konversi Energi Uji Coba Lapangan Pada Aspek Kualitas Teknis atau Tampilan

\begin{tabular}{|c|c|c|c|c|c|c|c|c|}
\hline \multirow{2}{*}{ No } & \multirow{2}{*}{ Indikator Penilaian } & \multicolumn{5}{|c|}{ Skor } & \multirow{2}{*}{$\begin{array}{l}\text { Rata- } \\
\text { rata }\end{array}$} & \multirow{2}{*}{ Kriteria } \\
\hline & & 1 & 2 & 3 & 4 & 5 & & \\
\hline 1 & Keindahan tampilan layar & & & & & 58 & $100,00 \%$ & Sangat Layak \\
\hline 2 & Kualitas teks & & & & 8 & 50 & $97,24 \%$ & Sangat Layak \\
\hline 3 & Kualitas gambar dan animasi & & & & 5 & 53 & $98,28 \%$ & Sangat Layak \\
\hline 4 & Komposisi warna & & & & 15 & 43 & $94,83 \%$ & Sangat Layak \\
\hline 5 & Navigasi & & & & 9 & 49 & $96,90 \%$ & Sangat Layak \\
\hline 6 & Daya dukung musik & & & & 8 & 50 & $97,24 \%$ & Sangat Layak \\
\hline 7 & Interaksi & & & & 2 & 56 & $99,31 \%$ & Sangat Layak \\
\hline & Rata-rat & & & & & & $98,08 \%$ & Sangat Layak \\
\hline
\end{tabular}

Tabel 3.Tingkat Kecencerungan Penilaian Terhadap Aspek Kualitas Materi Pembelajaran Media Pembelajaran Interaktif Pada Mata Pelajaran Konversi Energi Pada Uji Coba Lapangan

\begin{tabular}{clccc}
\hline No & \multicolumn{1}{c}{ Kategorisasi } & Rentang Skor & Frekuensi & Persentase (\%) \\
\hline 1 & Sangat Layak & $81 \% \leq \mathrm{X} \leq 100 \%$ & 58 & $100,00 \% \%$ \\
2 & Layak & $61 \% \leq \mathrm{X} \leq 80 \%$ & 0 & $0,00 \%$ \\
3 & Sedang & $41 \% \leq \mathrm{X} \leq 60 \%$ & 0 & $0,00 \%$ \\
4 & Kurang Layak & $21 \% \leq \mathrm{X} \leq 40 \%$ & 0 & $0,00 \%$ \\
5 & Sangat kurang & $0 \% \leq \mathrm{X} \leq 20 \%$ & 0 & $0,00 \%$ \\
\hline \multicolumn{2}{r}{} & & 58 & $100,00 \%$ \\
\hline
\end{tabular}

Tabel 4. Tingkat Kecenderungan Penilaian Terhadap Aspek Kualitas Teknis/Tampilan Media Pembelajaran Interaktif Konversi Energi Pada Uji Coba Lapangan

\begin{tabular}{clccc}
\hline No & \multicolumn{1}{c}{ Kategorisasi } & Rentang Skor & Frekuensi & Persentase \\
\hline 1 & Sangat Layak & $81 \% \leq \mathrm{X} \leq 100 \%$ & 58 & $100,00 \%$ \\
2 & Layak & $61 \% \leq \mathrm{X} \leq 80 \%$ & 0 & $0,00 \%$ \\
3 & Sedang & $41 \% \leq \mathrm{X} \leq 60 \%$ & 0 & $0,00 \%$ \\
4 & Kurang Layak & $21 \% \leq \mathrm{X} \leq 40 \%$ & 0 & $0,00 \%$ \\
5 & Sangat kurang & $0 \% \leq \mathrm{X} \leq 20 \%$ & 0 & $0,00 \%$ \\
\hline & & & $\mathbf{5 8}$ & $\mathbf{1 0 0 , 0 0 \%}$ \\
\hline
\end{tabular}




\section{Analisis I; Analisis Data Hasil Validasi Produk Awal}

Hasil penilaian oleh ahli materi, ahli desain pembelajaran dan ahli rekayasa perangkat lunak pada setiap aspek penilaian secara keseluruhan ditentukan oleh skor rata-rata pada kategorinya masing-masing. Hasil penilaian tersebut kemudian dianalisis untuk menentukan layak tidaknya, dikembangkan media pembelajaran interaktif pada matapelajaran konversi energi. Adapun persentase rata-rata dari hasil penilaian ahli materi, ahli desain pembelajaran dan ahli rekayasa perangkat lunak akan diuraikan sebagai berikut.

Tabel 5. Persentase Rata-Rata Hasil Penilaian Terhadap Media Pembelajaran Interaktif Pada Mata Pelajaran Mesin Konversi Energi Oleh Ahli Materi

\begin{tabular}{clcc}
\hline No & \multicolumn{1}{c}{ Kategorisasi } & \% Rata-rata & Kriteria \\
\hline 1 & Aspek materi pembelajaran & $95,00 \%$ & Sangat Layak \\
2 & Aspek strategi pembelajaran & $94,00 \%$ & Sangat Layak \\
3 & Aspek sistem penyampaian pembelajaran & $92,50 \%$ & Sangat Layak \\
\hline \multicolumn{2}{c}{ Rata-rata } & $93,83 \%$ & Sangat Layak \\
\hline
\end{tabular}

\section{Analisis Data Hasil Evaluasi Ahli Desain Pembelajaran}

Tabel 6. Persentase Rata-Rata Hasil Penilaian Terhadap Media Pembelajaran Interaktif Mata Pelajaran Mesin Konversi Energi Oleh Ahli Desain Pembelajaran

\begin{tabular}{clcc}
\hline No & \multicolumn{1}{c}{ Kategorisasi } & \% Rata-rata & Kriteria \\
\hline 1 & Kualitas desain pembelajaran & $87,50 \%$ & Sangat Layak \\
2 & Kualitas desain informasi & $87,50 \%$ & Sangat Layak \\
3 & Kualitas desain interaksi & $92,50 \%$ & Sangat Layak \\
4 & Kualitas Desain Presentasi & $81,70 \%$ & Sangat Layak \\
\hline & Rata-rata & $87,30 \%$ & Sangat Layak \\
\hline
\end{tabular}

Analisis Data Hasil Evaluasi Ahli Rekayasa Perangkat Lunak

Tabel 7. Persentase Rata-Rata Hasil Penilaian Terhadap Media Pembelajaran Interaktif Pada Mata Pelajaran Mesin Konversi Energi Oleh Ahli Rekayasa Perangkat Lunak.

\begin{tabular}{|c|c|c|c|}
\hline No & Kategorisasi & \% Rata-rata & Kriteria \\
\hline 1 & Pemprograman & $92,50 \%$ & Sangat Layak \\
\hline 2 & Kualitas teknis atau tampilan & $95,70 \%$ & Sangat Layak \\
\hline & Rata-rata & $94,10 \%$ & Sangat Layak \\
\hline
\end{tabular}

\section{Analisis II; Analisis Data Hasil Uji Coba Tahap II Uji Coba Perorangan}

Tabel 8. Persentase Rata-Rata Hasil Penilaian Terhadap Media Pembelajaran Interaktif Pada Mata Pelajaran Mesin Konversi Energi Pada Uji Coba Perorangan

\begin{tabular}{|c|c|c|c|}
\hline No & Kategorisasi & \% rata-rata & Kriteria \\
\hline 1 & Aspek kualitas materi pembelajaran & $93,33 \%$ & Sangat Layak \\
\hline 2 & Aspek kualitas teknis/tampilan & $89,52 \%$ & Sangat Layak \\
\hline & Rata-rata & $91,43 \%$ & Sangat Layak \\
\hline
\end{tabular}

\section{Analisis III; Analisis Data Hasil Uji Coba Tahap III Uji Coba Kelompok Kecil.}

Tabel 9. Persentase Rata-Rata Hasil Penilaian Terhadap Media Pembelajaran Interaktif Pada Mata Pelajaran Mesin Konversi Energi Pada Uji Coba Kelompok Kecil

\begin{tabular}{|c|c|c|c|}
\hline No & Kategorisasi & $\%$ rata-rata & Kriteria \\
\hline 1 & Aspek kualitas materi pembelajaran & $91,39 \%$ & Sangat Layak \\
\hline 2 & Aspek kualitas teknis/tampilan & $95,87 \%$ & Sangat Layak \\
\hline & Rata-rata & $95,87 \%$ & Sangat Layak \\
\hline
\end{tabular}




\section{Analisis IV; Analisis Data Hasil Uji Coba Tahap IV Uji Coba Lapangan}

Tabel 10. Persentase Rata-Rata Hasil Penilaian Terhadap Media Pembelajaran Interaktif Pada Mata Pelajaran Mesin Konversi Energi Pada Uji Coba Lapangan

\begin{tabular}{cccc}
\hline No & Kategorisasi & \% rata-rata & Kriteria \\
\hline 1 & Aspek kualitas materi pembelajaran & $97,84 \%$ & Sangat Layak \\
2 & Aspek kualitas teknis/tampilan & $98,08 \%$ & Sangat Layak \\
\hline & Rata-rata & $\mathbf{9 7 , 9 6 \%}$ & Sangat Layak \\
\hline
\end{tabular}

\section{Hasil Penelitian Uji Keefektifan Produk}

Setelah dilakukan uji kelayakan data selesai maka selanjutnya dilakukan uji t pretes penelitian. Hal ini dilakukan untuk mengetahui apakah terdapat perbedaan kemampuan awal kelas kontrol dan kelas eksperiman dengan menggunakan uji t pretes. Berdasarkan hasil perhitungan pada diperoleh output $t_{\text {hitung }}$ sebesar $-1,385$ dan $t_{\text {tabel }}$ sebesar 1,67 pada taraf kepercayaan 95 persen. Maka diperoleh bahwa $\mathrm{t}_{\text {hitung }}<\mathrm{t}_{\text {tabel }}$ atau $-1,385<1,67$ atau dengan kata lain $\mathrm{Ha}$ ditolak. Hal ini menujukkan bahwa kemampuan awal siswa baik kelas kontrol dan kelas eksperimen adalah cenderung sama dan tidak berbeda secara signifikan.

\section{Uji t postes}

Ho : $\mu_{1}=\mu_{2}$

$\mathrm{Ha}: \mu_{1}>\mu_{2}$

Keterangan :

$\mu_{1}=$ Rata-rata hasil belajar siswa yang diajar menggukan media pembelajaran interaktif.

$\mu_{2}=$ Rata-rata hasil belajar siswa yang diajar dengan pembelajaran konvensional.

Ho = Tidak ada perbedaan hasil belajar mesin konversi energi siswa yang diajar dengan menggunakan media pembelajaran interaktif dari siswa yang diajar dengan pembelajaran konvensional.

$\mathrm{Ha}=$ Ada perbedaan hasil belajar mesin konversi energi siswa yang diajar dengan menggunakan media pembelajaran interaktif lebih tinggi dari siswa yang diajar dengan pembelajaran konvensional.
Setelah dilakukan uji t pretes selesai maka selanjutnya dilakukan pengujian hipotesis penelitian dengan menggunakan uji $\mathrm{t}$ postes. Hal ini dilakukan untuk mengetahui apakah ada perbedaan hasil belajar siswa setelah dilakukan perlakuan yang berbeda.

Berdasarkan hasil perhitungan diperoleh output $t_{\text {hitung }}$ sebesar 3,285 dan $t_{\text {tabel }}$ sebesar 1,67 pada taraf kepercayaan 95 persen. Maka diperoleh bahwa $t_{\text {hitung }}>t_{\text {tabel }}$ atau 3,285 > 1,67 atau dengan kata lain $\mathrm{H} 0$ di tolak dan $\mathrm{Ha}$ diterima. Berdasarkan data-data di atas maka disimpulkan bahwa hasil belajar mesin konversi energi siswa yang diajar dengan menggunakan media pembelajaran interaktif lebih tinggi dari siswa yang diajar dengan media pembelajaran power point teruji kebenarannya. Hal ini berarti hasil belajar siswa yang menggunakan media pembelajaran interaktif lebih tinggi dari hasil belajar siswa yang diajar dengan media pembelajaran power point dengan efektifitas penggunaan media interaktif sebesar 80,46\%.

Kefektifan media pembelajaran interaktif diperoleh dengan cara sebagai berikut:

$$
\begin{aligned}
X & =\frac{\text { jumlah skor yang diperoleh }}{\text { jumlah skorideal }} \times 100 \% \\
X & =\frac{350}{435} \times 100 \% \\
& =80,46 \%
\end{aligned}
$$

Nilai keefektifan media pembelajaran interaktif ini lebih tinggi dari nilai keefektifan pembelajaran media pembelajaran power point yaitu sebesar $71,72 \%$ yang diuraikan sebagai berikut:

$$
\begin{aligned}
X & =\frac{\text { jumlah skor yang diperoleh }}{\text { jumlah skorideal }} \times 100 \% \\
X & =\frac{312}{435} \times 100 \% \\
& =71,72 \%
\end{aligned}
$$


Tabel 11. Rangkuman Persentase Rata-Rata Hasil Penilaian Terhadap Media Pembelajaran Interaktif Pada Mata Pelajaran Mesin Konversi Energi

\begin{tabular}{cllc}
\hline No & \multicolumn{1}{c}{ Responden } & \% Rata-rata & Kriteria \\
\hline 1 & Ahli materi & $93,83 \%$ & Sangat Layak \\
2 & Ahli desain pembelajaran & $88,55 \%$ & Sangat Layak \\
3 & Ahli rekayasa perangkat lunak & $94,10 \%$ & Sangat Layak \\
4 & Siswa pada uji coba perorangan & $91,43 \%$ & Sangat Layak \\
5 & Siswa pada uji coba kelompok kecil & $93,63 \%$ & Sangat Layak \\
6 & Siswa pada uji coba lapangan & $97,96 \%$ & Sangat Layak \\
\hline \multicolumn{2}{c}{ Rata-Rata } & $93,25 \%$ & Sangat Layak \\
\hline
\end{tabular}

\section{PEMBAHASAN}

Produk pengembangan media pembelajaran interaktif pada mata pelajaran mesin konversi energi merupakan materi pembelajaran yang telah dikembangkan dengan memperhatikan aspek pembelajaran dan media sebagai prinsip desain pesan pembelajaran. Penelitan pengembangan produk yang dilakukan ini diarahkan untuk menghasilkan suatu produk berupa media pembelajaran interaktif pada mata pelajaran konversi energi untuk siswa SMK Negeri 2 Kisaran Program studi keahlian teknik otomotif semester II (genap) yang digunakan untuk meningkatkan proses pembelajaran maupun kompetensi siswa. Oleh sebab itu proses penelitian ini dilakukan dan diawali dengan, (1) studi pendahuluan, (2) kemudian mendesain media pembelajaran, (3) melakukan validasi produk dan melakukan revisi dan penyempurnaan berdasarkan analisis data validasi dari ahli materi, (4) ahli desain pembelajaran dan ahli rekayasa perangkat lunak yang dilanjutkan dengan uji coba perorangan, uji coba kelompok kecil, dan uji coba lapangan sehingga dihasilkan media pembelajaran yang layak digunakan sesuai dengan karakteristik mata pelajaran dan siswa sebagai pengguna. Hal ini sejalan dengan pendapat Borg dan Gall (1983:772) pada buku Education Research an Introduction yang mengemukakan bahwa penelitian pengembangan adalah penelitian yang berorientasi untuk mengembangkan dan memvalidasi produk-produk yang digunakan dalam pendidikan.

Beberapa kegunaan dan manfaat dalam penggunaan media pembelajaran interaktif pada mata pelajaran konversi energi sebagai berikut: (1) materi mudah dipahami karena konsep yang disajikan direncanakan untuk mempermudah siswa dan sistematis, (2) media pembelajaran interaktif memberi kesempatan siswa untuk belajar sesuai dengan kecepatan masing-masing individu, (3) belajar lebih cepat dan menarik sehingga tidak menimbulkan kebosanan karena dilengkapi dengan gambargambar dan animasi serta soal latihan yang bervariasi. (4) adanya kesempatan dalam menjawab soal pada waktu tes jika jawaban dianggap salah dengan tujuan agar siswa dapat memahami materi yang telah dipelajari, (5) media pembelajaran interaktif ini juga dapat digunakan sebagai alternatif media pembelajaran secara konvensional maupun individual.

Sebuah media bisa dikatakan Layak setelah memperlihatkan hasil yang memuaskan dalam mencapai tujuan yang telah ditentukan. Dalam hal ini, maka dilakukanlah uji coba produk pada proses pembelajaran untuk mengetahui efektifitas pembelajaran. Efektifitas media itu, didapat dari nilai hasil belajar siswa. Miarso (2011:536) indikator yang dapat digunakan untuk menentukan efektivitas dalam proses pembelajaran adalah : (a) pengorganisasian materi yang baik, (b) komunikasi yang efektif, (c) penguasaan dan antusiasme terhadap materi pelajaran, (d) sikap positif terhadap siswa, (e) pemberian nilai yang adil, (f) keluwesan dalam pendekatan pembelajaran, dan $(\mathrm{g})$ hasil belajar siswa yang baik.

Dari hasil pengolahan data penelitian yang dilakukan, terdapat perbedaan hasil belajar mata pelajaran mesin konversi energi antara siswa yang dibelajarkan dengan menggunakan media pembelajaran interaktif dan siswa yang dibelajarkan dengan tanpa menggunakan media pembelajaran interaktif yaitu rata-rata hasil belajar mesin konversi energi siswa yang dibelajarkan dengan menggunakan media pembelajaran interaktif lebih tinggi yaitu sebesar $80,46 \%$ dibandingkan dengan siswa 
yang dibelajarkan tanpa menggunakan media pembelajaran interaktif yaitu sebesar $71,72 \%$. Dari data ini membuktikan bahwa penggunaan media pembelajaran interaktif lebih Layak dalam meningkatkan kompetensi dan pengetahuan siswa pada mata pelajaran mesin konversi energi daripada tanpa menggunakan media pembelajaran interaktif. Hasil penelitian ini sejalan dengan Ligin (2012) dalam pengembangan media pembelajaran interaktif pada mata pelajaran Geografi menggunakan perangkat lunak program Macromedia Flash professional 8.0 membuktika bahwa media pembelajaran intraktif memiliki keaktifan sebesar 82,55\% lebih tinggi dari pada keefektifan media pembelajaran power point sebesar 77,84\%. Dalam pengembangan digunakan perpaduan model media pembelajaran interaktif dari Borg and Gall dan Dick and Carey.

Johnson (2012) dalam pengembangan media pembelajaran interaktif pada mata pelajaran Matematika menggunakan perangkat lunak program Macromedia Flash Professional 8.0 membuktikan bahwa media pembelajaran interaktif memiliki keefektifan sebesar $70.73 \%$ lebih tinggi dari pada keefektifan menggunakan media pembelajaran power point sebesar $60,32 \%$.

\section{PENUTUP}

Hasil validasi dari ahli materi, ahli desain pembelajaran dan ahli media pembelajaran terhadap media pembelajaran interaktif pada mata pelajaran konversi energi yang dikembangkan dengan Software Macromedia Flash Professioanl 8.0 menunujukkan bahwa keseluruhan rata-rata dikategorikan "Sangat Layak" setelah dilakukan beberapa revisi sehingga media tersebut dapat digunakan untuk uji coba selanjutnya. Hasil validasi dari uji coba perorangan, uji coba kelompok kecil, dan uji coba lapangan terbatas terhadap media yang dikembangkan dengan Software Macromedia Flash Professioanl 8.0 termasuk dalam kategori "Sangat Layak" sehingga dapat diterima dan layak digunakan sebagai media belajar.

Penggunaan media pembelajaran interaktif lebih efektif dapat meningkatkan hasil belajar bila dibandingkan dengan menggunakan media power point, media pembelajaran interaktif memiliki keefektifan sebesar 80,46\% lebih tinggi dari keefektifan media pembelajaran power point sebesar 71,72\%.

\section{DAFTAR PUSTAKA}

AECT. 1977. Definisi Teknologi Pendidikan (satuan tugas definisi \& terminologi AECT). Jakarta: Rajawali.

Anas, Y. 2007. Pembelajaran dan Instruksi Pendidikan.

Yogyakarta: IRCiSoD.

Arifin. Zainal. Adhi. 2012. Pengembangan Pembelajaran Aktif dengan ICT. Yogyakarta: Skripta Media Creative.

Arifin Ahmad. Zainal. 2012. Perencanaan Pembelajaran dari Desain sampai Implementasi. Yogyakarta: Pedagogia.

Arsyad, A. 1997. Media Pengajaran. Jakarta : Raja Grafindo Persada.

Binanto, Iwan. 2010. Multimedia Digital Dasar Teori dan Pengembangannya. Jogyakarta:Andi Offset.

Borg, W. \&V Gall, M.D. 1983. Educational Research. An Introduction ( $4^{\text {nd }}$ ed). New York \& London: Longman.

Brown, H. Douglas, 2001. Teaching by Principles. An Interactive Approach to Language Pedagogy. White Plains, New York: Addison Wesley Longmasn, Inc.

Budiningsih, A. 2003. Desain Pesan Pembelajaran. Yogyakarta : FIP. Universitas Negeri Yogyakarta.

Depdiknas. 2006. Pengembangan Bahan Ajar. Materi 13-Sosialisasi KTSP/Pelatihan.

Dick, W. dan Carey, L. 2005. The Systematic Design of Instruction. United States of America: Scott Foresman and Company.

Frenkel, J.R. dan Wallen, N.E. 1993. How To Design and Evaluate Research in Education. New York: Mc. Graw Hill Inc.

Gagné, R.M.;Briggs, L.J \& Wager, W.W. 1992. Principles of Instruction Design. New York: Saunders College Publishing.

Gora. Winastawan, Sunarto. 2010. Pakematik Strategi Pembelajaran Inovatif Berbasis TIK. Elek Media Komputindo.

Hacbarth, S. 1996. The Educational Technology Hand Book. New Jersey: Educational Technology Publications, Inc. 
Hakim, L. 2004. Cara Ampuh Menguasai Macromedia Flash Professional 8.0. Jakarta: PT Elex Media Komputindo.

Hamruni. 2012. Strategi Pembelajaran. Yogyakarta: Insan Madani.

Hannafin, M. J., Peck, L. L. 1998. The Design Development and Education of Instructional Software. New York: Mc. Millan Publ., Co.

Heinich, Robert, et. Al. 1996 Instructional Media and Technologies for Learning $\left(5^{\text {th }}\right.$ ed $)$. New Jersey : A Simon \& Schuster Company Engelewood Cliffs.

Heinich, Robert. 1970. Technology and The Management Of Instruction. Washington D.C. : Association For Educational Communications and Technology.

Istiningsih. 2012. Pemanfaatan TIK dalam Pembelajaran. Yogyakarta: Skripta Media Creative.

Kemp. 1994. Design Effective Instruction. New York: Macmillan College Publishing Company.

Miarso, Y. 2004. Menyemai Benih Teknologi Pendidikan. Jakarta: Pustekkom.

Merrill. M.D. 1977. Teaching Concepts: An Instructional Design Guide. New Jersey: Educational Technology Publications

Munthe. Bermawy. 2012. Desain Pembelajaran. Yogyakarta: Pustaka Insan Madani.

Narwanti. Sri. 2011. Creative Learning. Yogyakarta: Familia

Prastowo. Andi. 2012. Pengembangan Sumber Belajar. Yogyakarta: Pedagogia.

Puspitosari. Heni A. 2010. Membuat Presentasi MultimediaTingkat Lanjut. Yogyakarta: Skripta Media Creative.

Putra. Nusa. 2011. Research and Development Penelitian dan Pengembangan: Suatu Pengantar. Jakarta: Raja Grafindo Persada.
Romiszowski. 1988. The Selection and Use of Instructional Media. United States: Nichols Publishing.

Silberman. Melvin L. 2007. Active Learning : 101 Strategi Pembelajaran Aktif. Yogyakarta: Pustaka Insan Madani.

Subini. Nini. 2012. Psikologi Pembelajaran. Yogyakarta: Mentari Pustaka.

Sadiman, A. dkk. 2003. Media Pendidikan, Pengertian, Pengembangan dan Pemanfaatannya . Jakarta : Pustekkom Dikbud.

Seells dan Richey. 1996. Instructional Technology (Mahasiswa S2 IKIP Malang Terjemahan). IKIP Malang

Sleeman, P. J. 1979. Instructional Media and Technology. New York: Long man Inc.

Slameto. 2010. Belajar dan Faktor-Faktor yang Mempengaruhi. Jakarta: Rineka Cipta.

Smaldino, E. S., dkk. 2008. Instrucional Technology and Media For Learning. New Jersey: Upper Saddle River.

Sudjana dan Rivai. 2005. Media Pengajaran. Bandung : Sinar Baru Algensindo

Suheri, A. 2006. Animasi Multimedia Pembelajaran. Jurnal Teknik Informatika Sekolah Tinggi Sains dan Teknologi Indonesia (ST- INTEN) Bandung.

Suparman, A. 2001. Desain instruksional. Pusat antar Universitas untuk Peningkatan dan Pengembangan Aktivitas Instruksional. Jakarta: Direktorat Jenderal Pendidkan Tinggi, Departemen Pendidikan Tinggi.

Sutopo, A. 2003. Multimedia Interaktif Dengan Flash. Yogyakarta: Graha Ilmu.

Uno, H. B. 2006. Perencanaan Pembelajaran. Jakarta: PT Bumi Aksara.

Wahana Komputer. 2004. Pembuatan CD Interaktif Dengan Macromedia Flash Professional 8.0 . Jakarta: Salemba Infotek. 